\title{
Analisis Pola Hubungan Kecerdasan Majemuk dengan Karakter Siswa Sekolah Menengah Pertama pada Kasus Gunung Meletus
}

\author{
Maryam Musfiroh*, Winny Liliawati, Heni Rusnayati, dan Nuryani Y. Rustaman
}

\begin{abstract}
Abstrak
Pendidikan karakter telah menjadi wacana yang hangat dibicarakan oleh para pakar pendidikan. Pasalnya, kasus-kasus moral yang sering terjadi pada beberapa siswa sekolah menengah pertama, khususnya di kota Bandung, disebabkan oleh pendidikan yang hanya menekankan pada aspek kognitif saja dengan mengabaikan penanaman karakter di dalamnya. Penelitian kualitatif dengan metode survey crossectional terhadap 40 siswa SMP kelas 9 di Kota Bandung telah memberikan suatu pola hubungan antara tipe kecerdasan siswa berdasarkan angket identifikasi kecerdasan majemuk yang diadaptasi dari model Howard Gardner dengan karakter siswa yang diukur melalui Tes Dilema Moral pada kasus gunung meletus. Pola tersebut menghasilkan siswa dengan kecerdasan Verbal-Linguistik; Logis-Matematis memiliki karakter tinggi pada Moral-Knowing. Siswa dengan kecerdasan Visual-Spasial; Musikal; dan Intrapersonal memiliki karakter tinggi pada Moral-Feeling. Sedangkan untuk Moral-Action, tingkatan tertinggi dimiliki oleh kelompok siswa dengan kecerdasan Kinestetik; Interpersonal; dan Naturalis.
\end{abstract}

Kata-kata kunci: Kecerdasan Majemuk, Karakter, Tes Dilema Moral (TDM)

\section{Pendahuluan}

Fungsi pendidikan adalah untuk membentuk bangsa yang cerdas dan berkarakter, sebagaimana yang tercantum dalam UU No 20 Tahun 2003. Akan tetapi, hasil studi pendahuluan berupa wawancara terhadap salah satu Guru IPA SMP di Kota bandung, mengakui bahwa pembelajaran di kelas cenderung hanya mengutamakan pengembangan kognitif peserta didik saja tanpa membangun karakter di dalamnya. Pendidik kurang mampu untuk membangun kecerdasan dan karakter peserta didik secara bersamaan. Mereka masih menganggap bahwa kecerdasan dan karakter adalah dua komponen pendidikan yang berdiri sendiri dan tidak saling berkaitan.

Metode pembelajaran yang dilakukan pun masih bersifat konvensional, peserta didik lebih banyak menghabiskan waktunya untuk mendengarkan penjelasan Guru. Hal ini membuat peserta didik mudah merasa jenuh di dalam kelas, bahkan ada beberapa peserta didik yang memilih untuk tidak masuk sekolah. Sebagaimana yang disebutkan oleh Howard Gardner bahwa manusia terlahir dengan membawa bakat dan kecerdasan yang beragam yang dikenal sebagai kecerdasan majemuk [1]. Sehingga pembelajaran pun harus dilakukan dengan metode yang variatif sesuai minat peserta didik.

Berdasarkan hasil studi pendahuluan tersebut, Peneliti merasa perlu untuk memgembangkan suatu pembelajaran yang mampu merangkul kedua aspek tersebut, yaitu kecerdasan majemuk dan karakter. Beberapa peneliti lain mulai mencoba mengembangkan model pembelajaran yang mampu menjawab permasalahan tersebut.

Apabila di tinjau dari kecerdasan majemuk yang dikembangkan selama pembelajaran, kecerdasan majemuk yang dominan/ kuat yang dapat berkembang yaitu verbal, visual, interpersonal dan intrapersonal, sedangkan kecerdasan majemuk yang masih rendah/ lemah yaitu naturalis, matematis logis, musikal dan kinestetis. Hal ini dapat menjelaskan mengapa karakter demokratif dan komunikatif terbangun lebih optimal dibanding yang lainnya karena karakter komunikatif didasari oleh kecerdasan verbal lingusitik, dan karakter demokratif didasari pula oleh kecerdasan verbal, interpersonal dan intrapersonal. Karakter berpikir logis, menggambar dan kepekaan terhadap fenomena alam yang rendah, ini juga dapat dijelaskan dari rendahnya kecerdasan naturalis, musikal, dan logis matematis. [2]

Walaupun telah dikembangkan beberapa model pembelajaran yang mengarah kesana, akan tetapi akan lebih baik jika terlebih dahulu mengetahui apakah ada hubungan antara kecerdasan majemuk dengan karakter? Jika ada, seperti apa hubungan antara keduanya? Berdasarkan pertimbangan tersebut, peneliti melakukan penelitian untuk mengungkap bagaimana hubungan antara kecerdasan majemuk dengan karakter. 


\section{Teori}

Gardner mendefinisikan kecerdasan sebagai kemampuan untuk memecahkan masalah dan menciptakan produk yang mempunyai nilai budaya [3]. Gardner menyediakan sarana untuk memetakan barbagai kemampuan yang dimiliki manusia, dengan mengelompokkan kemampuan-kemampuan mereka ke dalam delapan kategori yang komprehensif atau "kecerdasan", yaitu:

1. Linguistik, yaitu Kemampuan untuk menggunakan kata-kata secara efektif, baik lisan maupun tulisan.

2. Logis-matematis, yaitu kemampuan menggunakan angka secara efektif.

3. Visual-spasial, yaitu kemampuan untuk memvisualisasikan, mewakili ide-ide visual atau spasial secara grafis, dan mengorientasikan diri secara tepat dalam sebuah matriks spasial.

4. Kinestetik-tubuh, yaitu keahlian menggunakan seluruh tubuh untuk mengekspresikan ide-ide dan perasaanperasaan dan kelincahan dalam menggunakan tangan seseorang untuk menciptakan atau mengubah sesuatu.

5. Musikal, yaitu kemampuan untuk merasakan, mengubah, dan mengekspresikan bentukbentuk musik.

6. Interpersonal, yaitu kemampuan untuk memahami dan membuat perbedaanperbedaan pada suasana hati, maksud, motivasi, dan perasaan terhadap orang lain.

7. Intrapersonal, yaitu pengetahuan diri dan kemampuan untuk bertindak secara adaptif berdasarkan pengetahuan itu.

8. Naturalis, yaitu keahlian dalam mengenali dan mengklasifikasikan berbagai spesies flora dan fauna, dari sebuah lingkungan individu. Hal ini juga mencakup kepekaan terhadap fenomena alam lainnya. [4]

Komponen utama lain dari pendidikan disamping kecerdasan adalah karakter. Karakter merupakan perwujudan dari kesadaran menjalankan peran, fungsi, dan tugasnya dalam mengemban amanah dan tanggung jawab. Karakter inilah yang menempatkan baik tidaknya seseorang. Posisi karakter bukan menjadi pendamping kompetensi, melainkan menjadi dasar, ruh, atau jiwanya. Tanpa karakter, peningkatan diri dari kompetensi bisa liar, berjalan tanpa rambu dan aturan.

Berdasarkan pemahaman ini, peneliti bermaksud untuk memberikan suatu cara berpikir tentang karakter yang tepat bagi pendidikan nilai, bahwa karakter terdiri dari nilai operatif, nilai dalam tindakan. Kita berproses dalam karakter kita, seiring suatu nilai menjadi suatu kebaikan, suatu disposisi batin yang dapat diandalkan untuk menanggapi situasi dengan cara yang menurut moral itu baik.

Karakter yang terasa demikian memiliki tiga bagian yang Saling berhubungan, sebagaimana yang dikemukakan oleh Lickona (2012), yaitu pengetahuan moral, perasaan moral, dan perilaku moral [5].

Kompenen karakter yang baik menurut Lickona adalah sebagai berikut.

1. Pengetahuan moral, terdiri dari:
a. kesadaran moral
b. pengetahuan nilai moral
c. penentuan perspektif
d. pemikiran moral
e. pengambilan keputusan
f. pengetahuan pribadi.

2. Perasaan moral, terdiri dari:
a. hati nurani
b. harga diri
c. empati
d. mencintai kebaikan
e. kendali diri
f. kerendahan hati.

3. Tindakan moral, terdiri dari:
a. Kompetensi
b. Keinginan
c. kebiasaan.

Ketiga hal ini diperlukan untuk mengarahkan suatu kehidupan moral dalam rangka membentuk kedewasaan moral. Ketika kita berpikir tentang jenis karakter yang kita inginkan bagi anak-anak kita, sudah jelas bahwa kita menginginkan anak-anak kita untuk mampu menilai apa yang benar, sangat peduli tentang apa yang benar, dan kemudian melakukan apa yang mereka yakini itu benar, meskipun berhadapan dengan godaan dari dalam dan tekanan dari luar. 


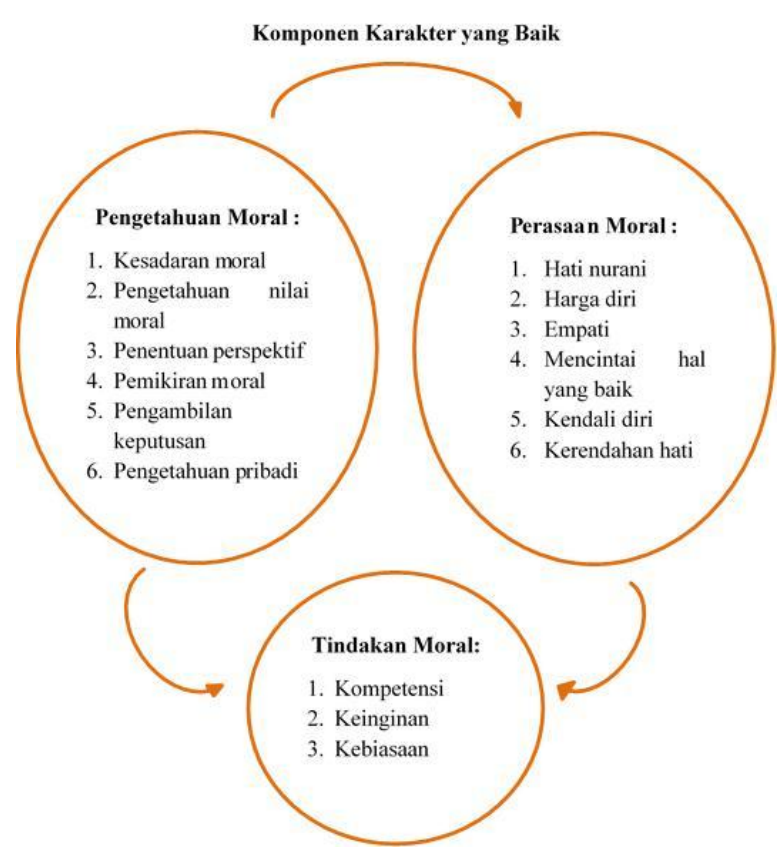

Gamabar 1. Komponen karakter yang baik

\section{Metode}

Penelitian ini menggunakan metode penelitian kualitatif untuk menentukan karakter siswa berdasarkan respon siswa ketika dihadapkan dalam suatu permasalahan atau kasus tertentu.[6]

Siswa dapat dikelompokkan berdasarkan kecerdasan yang dimilikinya. Pengelompokkan ini diperoleh dari hasil angket identifikasi kecerdasan majemuk yang diadopsi dari tes identifkasi kecerdasan model kecerdasan Howard Gardner yang dikembangkan oleh Thomas Armstrong. Angket tersebut berisi 80 pernyataan dengan masing-masing kecerdasan diwakili oleh sepuluh pernyataan.

Setelah diperoleh 5 siswa pada masingmasing kecerdasan, kemudian diberikan suatu tes untuk mengukur sejauh mana pengetahuan moral, perasaan moral, dan tindakan moral yang tertanam dalam diri siswa. Instrumen yang digunakan untuk mengukur karakter siswa tersebut dinamakan tes dilema moral dengan mengangkat kasus-kasus bertema gunung meletus. Kasus-kasus tersebut dirancang sedemikian rupa sehingga mampu menciptakan pemikiran dan perasaan dilematis dalam diri siswa.

Siswa mengungkapkan apa yang mereka pikirkan, rasakan, dan rencana tindakan yang akan dilakukan setelah membaca kasus yang disajikan. Data siswa berupa uraian bebas kemudian dianalisis berdasarkan komposisi karakter yang terkandung di dalam uraian tersebut.

\section{Hasil dan Diskusi}

Hampir semua siswa pada kecerdasan yang sejenis memberikan gejala karakter yang sama, sehingga berdasarkan analisis data, peneliti menemukan suatu pola tertentu yang menghubungkan antara tipe kecerdasan siswa dengan tipe karakter dominan pada diri siswa. Pola tersebut disajikan dalam tabel berikut.

Tabel 1. Persentase komponen karakter pada masing-masing kecerdasan

\begin{tabular}{cccc}
\hline Kecerdasan & \multicolumn{3}{c}{ Karakter } \\
\cline { 2 - 4 } Majemuk & Pengetahuan & Perasaan & Tindakan \\
\hline Linguistik & $\mathbf{5 6 , 6 7 \%}$ & $50,00 \%$ & $46,67 \%$ \\
Logis & $\mathbf{7 0 , 0 0 \%}$ & $63,33 \%$ & $60,00 \%$ \\
Visual & $\mathbf{4 6 , 6 7 \%}$ & $\mathbf{6 6 , 6 7} \%$ & $\mathbf{4 6 , 6 7 \%}$ \\
Kinestetik & $53,33 \%$ & $53,33 \%$ & $\mathbf{6 0 , 0 0 \%}$ \\
Musikal & $63,33 \%$ & $\mathbf{6 6 , 6 7} \%$ & $53,33 \%$ \\
Interpersonal & $60,00 \%$ & $63,33 \%$ & $\mathbf{6 6 , 6 7} \%$ \\
Intrapersonal & $53,33 \%$ & $\mathbf{6 0 , 0 0} \%$ & $53,33 \%$ \\
Naturalis & $50,00 \%$ & $53,33 \%$ & $\mathbf{6 0 , 0 0 \%}$ \\
\hline
\end{tabular}

Dari tabel tersebut diperoleh suatu gambaran bahwa siswa dengan kecerdasan verballinguistik memiliki pengetahuan moral yang lebih tinggi ketika dihadapkan pada suatu kasus atau permasalahan ketimbang merasakan dan merealisasikannya dalam bentuk tindakan, hal yang sama dialami oleh siswa dengan kecerdasan logis-matematis. Siswa dengan kecerdasan visual-spasial, musikal, dan intrapersonal cenderung mengutamakan perasaannya daripada berpikir dan bertindak. Sedangkan siswa dengan kecerdasan kinestetik, interpersonal, dan naturalis cenderung mengedepankan tindakan dalam menyelesaikan masalah.

Walaupun dari hasil analisis diperoleh nilai yang paling tinggi dalam aspek karakter tertentu, bukan berarti memiliki nilai rendah pada aspek yang lainnya. Persentase yang ditunjukkan dalam tabel pun mengindikasikan bahwa setiap siswa memiliki aspek pengetahuan, perasaan, dan tindakan moral yang hampir seimbang. Hanya saja pengelompokkan ini dimaksudkan untuk melihat di ranah karakter mana yang menjadi unggulan siswa, sehingga keuntungannya dalam pembelajaran, pendidik dapat menerapkan metode yang sekiranya efektif diterima oleh siswa sesuai karakter yang dimiliki siswa.

\section{Kesimpulan}

Hasil analisis memberikan suatu pola antara kecerdasan majemuk dengan karakter peserta didik. Pola tersebut antara lain, siswa dengan kecerdasan Verbal-Linguistik dan Logis- 
Matematis memiliki karakter tinggi pada MoralKnowing. Siswa dengan kecerdasan VisualSpasial; Musikal; dan Intrapersonal memiliki karakter tinggi pada Moral-Feeling. Sedangkan untuk Moral-Action, tingkatan tertinggi dimiliki oleh kelompok siswa dengan kecerdasan Kinestetik; Interpersonal; dan Naturalis.

\section{Ucapan terima kasih}

Penulis mengucapkan terima kasih kepada rekan- rekan mahasiswa departemen Pendidikan Fisika yang ikut membantu dalam penelitian ini yaitu Elis Yudianingsih, Maryam Fauziyah, Sri Wulandari, dan Diana Safitri. Juga kepada dosen-dosen pembimbing yang telah membantu baik secara finansial maupun arahan yang membangun demi perbaikan penelitian ini yaitu Ibu Winny Liliawati, Ibu Heni Rusnayati, dan Ibu Nuryani Y. Rustaman.

\section{Referensi}

[1] Thomas Armstrong, "Kecerdasan Multipel di dalam Kelas", Penerbit PT Indeks, Jakarta, 2013

[2] Winny Liliawati, dkk, "Analisis Karakter Diri Mahasiswa Yang Terbangun Melalui Perkuliahan Ipba Terintegrasi Berbasis Kecerdasan Majemuk", Prosiding Seminar Nasional Penelitian, UNY, 2012

[3] Thomas Armstrong, "Kecerdasan Multipel di dalam Kelas", Penerbit PT Indeks, Jakarta, 2013, p. 19

[4] Thomas Armstrong, "Kecerdasan Multipel di dalam Kelas", Penerbit PT Indeks, Jakarta, 2013, p. 6-7

[5] Thomas Lickona, "Character Matters, Persoalan Karakter. Bagaimana Membantu Anak Mengembangkan Penilaian yang Baik, Integritas, dan Kebijakan Penting Lainnya", Penerbit PT Bumi Aksara, jakarta, 2012, p. 81

[6] Adib Rifqi Setiawan. Panduan Penulisan Artikel. Alobatnic.blogspot.com, 2019. URL: https://alobatnic.blogspot.com/2019/04/pand uan-penulisan-artikel.html

Maryam Musfiroh* Departemen

Pendidikan Fisika

Universitas Pendidikan Indonesia

1204817musfirohmaryam@gmail.com

Winny Liliawati

Departemen Pendidikan Fisika

Universitas Pendidikan Indonesia

Winny.liliawati@gmail.com

${ }^{*}$ corresponding author 
